\title{
Penerapan E-Learning dalam Pembelajaran Membaca Bahasa Indonesia Kelas IV SDN Margomulyo 1 Ngawi Tahun Pelajaran 2021/2022
}

Takiyatul Aminin $\bowtie$, Universitas PGRI Madiun

Dwi Setyadi, Universitas PGRI Madiun

Sigit Ricahyono, Universitas PGRI Madiun

takiyatulaminin@gmail.com

\begin{abstract}
Abstrak: Penggunaan E-learning di jenjang pendidikan Sekolah Dasar merupakan teknologi pembelajaran yang masih awam dan jarang digunakan. Akan tetapi, sekarang pendidik dan siswa harus mampu melaksanakan $E$ learning. Penelitian ini bertujuan untuk menjelaskan penerapan E-Learning dalam Pembelajaran membaca bahasa Indonesia kelas IV di SDN Margomulyo I Tahun Pelajaran 2021/2022. Subjek penelitian ini adalah guru Sekolah Dasar kelas IV SDN Margomulyo I. Pada penelitian ini, peneliti menggunakan metode analisis kualitatif deskriptif melalui wawancara terhadap guru kelas IV SDN Margomulyo I. Hasil penelitian menemukan bahwa Pelaksanaan pembelajaran e-learning di SDN Margomulyo I khususnya membaca dilakukan dengan menggunakan media online yang beragam yaitu google classroom, youtube, Zoom, whatsApp, google workspace for education, google meet, google slide dan google doc. Pengembangan sistem Pembelajaran berbasis internet di SDN Margomulyo I Mengunakan Web centric course atau penggunaan internet yang memadukan antara belajar jarak jauh dan tatap muka, fungsinya saling melengkapi, dalam model ini guru memberikan petunjuk pada siswa untuk mempelajari materi melalui web yang telah dibuat oleh guru.
\end{abstract}

Kata kunci: Metode pembelajaran, E-Learning, Membaca.

Abstract: Making use of E-learning at the elementary school level is a learning technology that is still uncommon and rarely used. However, nowadays teachers and students must be able to implement E-learning. This study aims to explain the application of E-Learning in learning to read Indonesian for the IV graders at Margomulyo 1 Elementary School in the schooling year of 2021/2022. The subject of this study is the fourth grade teacher of Margomulyo 1 Elementary School. In this study, the researcher used a descriptive qualitative method through interviews with the fourth grade teacher at Margomulyo 1 Ngawi. The results of the study show that the implementation of e-learning at Margomulyo 1 Elementary School, especially reading is by using various online media, i.e. google classroom, youtube, zoom, whatsapp, google workspace for education, google meet, google slide and google doc. Development of an internet-based learning system at SDN Margomulyo I was by using using a Web centric course or the internet that combines distance and face-to-face learning. The functions are complementary to each other. In this model the teacher gave instructions to the students to learn materials through the web that was created by the teacher.

Keywords: Learning Methods, E-Learning, Reading.

Citation: Aminin, T., Setyadi, D., \& Ricahyono, S. (2022). Penerapan E-Learning dalam Pembelajaran Membaca Bahasa Indonesia Kelas IV SDN Margomulyo 1 Ngawi Tahun Pelajaran 2021/2022. Wewarah: Jurnal Pendidikan Multidisipliner, 1(1), 18 - 23.

\section{(cc) EY}

Published by Program Pascasarjana Universitas PGRI Madiun. This work is licensed under the Creative Commons AttributionNonCommercial-ShareAlike 4.0 International License. 


\section{PENDAHULUAN}

\section{Latar Belakang}

Sejak Desember tahun 2019, diseluruh dunia sedang mengalami wabah atau virus yang sama yaitu pandemi covid -19. Menteri Pendidikan dan Kebudayaan Nadiem Anwar Makariem menerbitkan Surat Edaran Nomor 4 Tahun 2020 tentang Pelaksanaan Pendidikan dalam Darurat Covid-19. Salah satunya mengenai proses belajar dirumah. Setelah adanya kebijakan mengenai pembelajaran dirumah dimasa pandemi Covid-19, sekolah-sekolah memutuskan untuk menggunakan beberapa aplikasi E-learning sebagai alternatif dalam pembelajaran. Beberapa aplikasi yang biasa digunakan diantaranya Google Classrom,Zoom, youtube, WhatsApp Group sebagai media pembelajaran.

Penerapan E Learning khususnya dalam pembelajaran Bahasa Indonesia, pendidik dihadapkan dengan sejumlah karakteristik peserta didik yang beraneka ragam. Ada peserta didik yang menempuh kegiatan belajarnya secara lancar dan keberhasilan tanpa mengalami kesulitan, namun di sisi lain tidak sedikit pula peserta didik yang justru dalam belajarnya mengalami berbagai kesulitan belajar yang ditunjukkan oleh hambatan-hambatan tertentu untuk mencapai hasil belajar, dapat bersifat psikologis, sosiologis maupun fisiologis sehingga pada akhirnya dapat menyebabkan prestasi belajar yang dicapai berbeda di bawah semestinya.

Berdasarkan observasi di SDN Margomulyo I, peneliti menemukan kendala bahwasanya dalam penerapan pembelajaran berbasis e-learning pada masa pandemi covid 19 khususnya mata pelajaran bahasa Indonesia tidak tersampaikan dengan baik, jam belajar yang tidak sesuai dengan jadwal, pemberian tugas sebagai pengganti jadwal pembelajaran.

\section{Rumusan Masalah}

Rumusan masalah pada penelitian ini adalah "Bagaimana Penerapan E-Learning Dalam Pembelajaran Membaca Bahasa Indonesia Kelas IV Tema Pahlawanku di SDN Margomulyo I Tahun Pelajaran 2021/2022?"

\section{Tujuan Penelitian}

Tujuan penelitian ini adalah untuk menjelaskan penerapan E-Learning dalam Pembelajaran membaca bahasa Indonesia kelas IV Tema Pahlawanku di SDN Margomulyo I Tahun Pelajaran 2021/2022.

\section{Manfaat penelitian}

Secara teoritik penelitian yang peneliti lakukan ini diharapkan mampu menjadi bahan kajian dan referensi dalam pengembangan keilmuan bidang pendidikan di Indonesia, membantu mendapatkan informasi ilmiah pada Pembelajaran berbasis E-learning serta sebagai bahan masukan bagi guru agar Pembelajaran berbasis E-learning ini tersampaikan dengan baik.

\section{Kajian Pustaka}

Rifa'i dan Anni (2012: 158) menyatakan bahwa Pembelajaran berorientasi pada bagaimana peserta didik berperilaku, memberikan makna bahwa Pembelajaran merupakan suatu kumpulan proses yang bersifat individual, yang merubah stimuli dari lingkungan seseorang kedalam sejumlah informasi yang selanjutnya menyebabkan adanya hasil belajar dalam membentuk ingatan jangka panjang. Pembelajaran yang mendidik memerlukan berbagai kompononen dalam proses Pembelajaran. Kompenen tersebut tediri dari: tujuan, subjek belajar, materi Pembelajaran, strategi, media, evaluasi dan penunjang. E-Learning merupakan proses Pembelajaran jarak jauh dengan menggabungkan prinsip-prinsip dalam proses Pembelajaran teknologi.

Menurut Efendi (2005: 6) terminologi E-learning sendiri dapat mengacu pada semua kegiatan pelatihan yang menggunakan media elektronik atau teknologi informasi. E-learning terdiri atas dua bagian yaitu "e" yang merupakan singkatan dari elektronik dan learning yang berarti Pembelajaran. Jadi E- learning berarti Pembelajaran menggunakan jasa/bantuan perangkat elektronika, khususnya perangkat komputer. Karena itu E-learning sering disebut dengan on-line course (Poppy, 2010). Elearning sebagai penyampaian program Pembelajaran pelatihan, atau pendidikan dengan menggunakan sarana elektronik seperti komputer atau alat elektronik lain seperti telepon genggam dengan berbagai 
cara untuk memberikan pelatihan, pendidikan, atau bahan ajar (Prawiradilaga, 2013). Munir (2009) mengungkapkan beberapa karakteristik E-learning yakni: "memanfaatkan teknologi, menggunakan media komputer, pendekatan mandiri, tersimpan dimedia komputer, otomatisasi proses Pembelajaran".

Ada tiga kemungkinan dalam pengembangan sistem Pembelajaran berbasis internet yaitu web course, web centric course, dan web enhaced course (Tafiardi,2005). Web Course adalah penggunaan internet untuk keperluan pendidikan, yang mana peserta didik dan pengajar sepenuhnya terpisah dan tidak diperlukan adanya tatap muka, Web centric course adalah penggunaan internet yang menggunakan atau memadukan antara belajar jarak jauh dan tatap muka, fungsinya saling melengkapi, dalam model ini pengajar dapat memberikan petunjuk pada siswa untuk mempelajari materi melalui web yang telah dibuatnya, Web enhanced course adalah pemanfaatan internet untuk menunjang peningkatan kualitas Pembelajaran yang dilakukan dikelas. Fungsi internet adalah untuk memberikan pengayaan dan komunikasi antara peserta didik dan pengajar, sesama peserta didik, anggota kelompok, atau peserta didik dengan narasumber lain.

Secara filosofis, pelaksanaan E-learning mengandung dua konsekuensi. Konsekuensi pertama, menuntut diterapkannya sistem belajar mandiri. Konsekuensi kedua dioptimalkan media komunikasi, khususnya teknologi komunikasi secara tepat guna dan sesuai kebutuhan. Belajar mandiri tidak berarti belajar sendiri. Hal yang terpenting dalam proses mandiri ialah peningkatan kemauan dan keterampilan siswa dalam proses belajar tanpa bantuan orang lain, sehingga akhirnya siswa tidak tergantung pada guru. (Kusuma,2011).

Proses Pembelajaran online dapat diselenggarakan dalam berbagai cara berikut (1) proses Pembelajaran secara konvensional (lebih banyak face to face meeting) dengan tambahan Pembelajaran melalui media interaktif komputer melalui internet atau menggunakan grafik interaktif komputer. (2) dengan metode campuran, yakni sebagian besar proses Pembelajaran dilakukan melalui komputer, namun juga tetap memerlukan face to meeting untuk kepentingan tutorial atau mendiskusikan bahan ajar. (3) metode Pembelajaran yang keseluruhan hanya dilakukan secara online, metode ini sama sekali tidak ditemukan face to face meeting.

Model Pembelajaran yang dikembangkan melalui E-learning menekankan pada resource based learning, yang juga dikenal dengan learner-centered learning. Dengan model ini peserta didik mampu mendapatkan bahan ajar dari tempatnya masing-masing (melalui personal computer di rumah masingmasing). Keuntungan model Pembelajaran seperti ini adalah tingkat kemandirian peserta didik menjadi lebih baik dan kemampuan teknik komunikasi mereka yang menunjukan kemajuan yang menggembirakan. Dengan model ini, komunikasi antar peserta didik pendidik berlangsung secara bersamaan atau sendiri-sendiri melalui jaringan komputer. E-Learning akan membentuk kebiasaan siswa untuk belajar mandiri, keterampilan berkomunikasi, kemampuan bernalar dan bersosialisasi. Selain itu, siswa akan mampu melakukan komunikasi dengan baik secara lisan maupun tertulis dengan orang lain. Tindakan yang dilakukan ialah berburu berbagai macam referensi sumber Pembelajaran yang dapat di download dan dipelajari secara mandiri oleh siswa, sehingga kemandirian belajar akan tercipta dengan sendirinya.

Pembelajaran berbasis E-learning dalam bahasa Indonesia dapat dilakukan ketika proses Pembelajaran bahasa berlangsung. Untuk mengajarkan keterampilan berbicara dapat menggunakan program audio yang terkoneksi satu dengan yang lainnya. Guru hanya mengawasi dan membimbingsiswa ketika proses Pembelajaran berlangsung. Misalnya, ketika siswa praktik membaca berita lewat Zoom Meeting, siswa yang lain akan menyimak, mencermati, dan mencatat apa yang dianggap penting. Setelah itu siswa akan saling berinteraksi (tanya jawab) dengan dipandu oleh guru. Siswa akan lebih antusias dan respon terhadap Pembelajaran bahasa tersebut. Contoh lain Pembelajaran Bahasa Indonesia dengan menggunakan E-learning adalah berdiskusi group dengan temannya. Kelompok belajar ini dapat membentuk komunitas, berkolaborasi, dan membentuk jaringan online yang dapat dilakukan secara langsung dan tidak langsung. Siswa dapat selalu berkomunikasi dengan temannya membahas Pembelajaran Bahasa Indonesia yang sudah dilakukan di sekolah. Apapun yang men- dukung Pembelajaran Bahasa Indonesia dapat dibahas dalam jaringan online.

\section{METODE}

Dalam melakukan penelitian ini, peneliti menggunakan pendekatan penelitian kualitatif, karena data 
yang diperoleh dilapangan lebih banyak bersifat informasi dan keterangan bukan dalam bentuk simbol atau angka. Penelitian kualitatif adalah pengumpulan data pada suatu latar alamiah, dengan menggunakan metode alamiah dan dilakukan peneliti tertarik secara alamiah (Moleong,2014). Penelitian ini dilakukan di SDN Margomulyo I Ngawi yang beralamat di Jalan Yos Sudarso No. 17B Kabupaten Ngawi Provinsi Jawa Timur. Kegiatan penelitian dilaksanakan di kelas IV pada semester ganjil (satu), dimulai bulan Juli sampai dengan Desember 2021, tahun Ajaran 2021/ 2022.

Sumber data dalam penelitian adalah subjek dari mana data dapat diperoleh baik berupa katakata, gambar, dan bukan angka-angka. Sumber data dalam penelitian ini yaitu mengambil sumber data primer dan sekunder. Sumber data primer dalam penelitian ini peneliti melakukan wawancara terhadap kepala sekolah, guru dan siswa berkaitan dengan Pembelajaran E-learning. Sumber data sekunder yang digunakan peneliti dalam penelitian ini, terdiri dari dokumen yang berupa profil SDN Margomulyo I, RPP, nilai siswa, jurnal artikel ilmiah yang berkaitan dengan Pembelajaran E-learning dan dokumentasi dari kegiatan Pembelajaran E-learning. Dalam mengumpulkan data peneliti di bantu teman sejawat sebagai dokumentasi akan kegiatan yang berlangsung di dalam penelitian.

Untuk memperoleh data/pengumpulan, peneliti mengumpulkan data dengan melakukan observasi, wawancara dan tes tulis. Dalam proses pengumpulan data yang dilakukan dengan observasi dan wawancara, peneliti bertindak sebagai pengamat partisipan pasif. Maka untuk itu peneliti harus bersikap sebaik mungkin, hati-hati dan sungguh-sungguh dalam menjaring data sesuai dengan kenyataan di lapangan sehingga data yang terkumpul benar-benar relevan dan terjamin keabsahannya. Peneliti mencari data melalui wawancara dengan wawancara terstruktur, wawancara terstruktur yaitu kegiatan wawancara yang dilakukan dimana peneliti telah mengetahui dengan pasti informasi apa yang hendak digali dari informan, seperti peneliti telah mempersiapkan daftar pertanyaan secara rinci dan juga telah mempersiapkan alat bantu rekam dan kamera untuk kebutuhan pengumpulan data. Dengan wawancara, peneliti dapat mengetahui hal-hal yang lebih mendalam tentang partisipan dalam menginterpretasikan situasi dan fenomena yang terjadi (Ibrahim, 2015).

Pengecekan keabsahan data dalam penelitian kualitatif dapat dilakukan dengan uji credibility (validitas interbal), transferability (validitas eksternal), dependability (reliabilitas) dan confirmability (obyektifitas). Untuk memeriksa keabsahan data dalam penelitian ini berdasarkan data yang sudah terkumpul, selanjutnya ditempuh beberapa teknik keabsahan data yang meliputi: kredibilitas, tranferabelitas, dependabilitas, dan konfirmabilitas. Dalam penelitian ini, penelliti menggunakan metode analisis deskriptif yaitu gambaran atau lukisan secara sistematis, faktual dan akurat mengenai fenomena atau hubungan antar fenomena yang diselidiki. Penelitian ini akan dianalisis secara kualitatif untuk mengolah data dari lapangan yaitu : 1) Pengumpulan Data, 2) Reduksi Data, 3) Penyajian Data, 4) Penarikan Kesimpulan dan Verifikasi (Sugiyono, 2016). Pengolahan atau analisis data dilakukan setelah adanya data terkumpul dari hasil pengumpulan data. Analisis data sering disebut sebagai pengolahan data. Ada yang menyebut data prepation, ada pula data analysis (Arikunto, $2006: 209$ ).

\section{HASIL DAN PEMBAHASAN}

Rifa'i dan Anni (2012: 158) menyatakan bahwa pembelajaran berorientasi pada bagaimana peserta didik berperilaku, memberikan makna bahwa pembelajaran merupakan suatu kumpulan proses yang bersifat individual, yang merubah stimuli dari lingkungan seseorang kedalam sejumlah informasi yang selanjutnya menyebabkan adanya hasil belajar dalam membentuk ingatan jangka panjang. Kartasamita (dalam Poppy, 2010) mengemukakan bahwa salah satu ciri E-learning adalah adanya pembelajaran dengan kombinasi teknologi dan berbagai terapan praktis, serta dengan kesegeraan kemudahan akses sumber belajar, ke pengajar dan kesesama pelajar, melalui internet.

Penerapan pembelajaran berbasis E-learning di SDN Margomulyo I sudah sangat relevan karena di SDN Margomulyo I sudah menggunakan pembelajaran E-learning dengan informasi dan teknlogi yang ada dan sudah tersedia sebelum adanya covid-19, yang digunakan sesuai jam mata pelajaran di labaratorium komputer. Sejalan dengan proses penerapan pembelajaran berbasis E-learning pada masa pandemi covid-19 di SDN Margomulyo I, hal ini menjadikan adanya perubahan dalam penerapan pembelajaran tatap muka, beralih pada pembelajaran e-learning. Pelaksanaan pembelajaran adalah suatu proses atau kegiatan pembelajaran yang dilakukan oleh guru untuk mecapai tujuan yang diharapkan, dalam pelaksanaan pembelajaran didalamnya berisi nilai pendidikan juga bimbingan dari pendidik kepada peserta didik. Pelaksanaan pembelajaran e-learning di SDN Margomulyo I diantaranya 
1) Penggunaan Aplikasi yang bervariasi

Penggunaan aplikasi ini digunakan untuk mendukung pembelajaran e-learning seperti google classroom, youtube, Zoom, dan whatsApp serta google workspace for education, google meet, google slide dan google doc. Dalam penggunaan aplikasi, menunjukan bahwa sekolah sangat mempersiapkan dalam melaksanakan pembelajaran e-learning, hal ini dibuktikan dengan adanya beberapa apalikasi yang digunakan. Selain aplikasi di atas dinas pendidikan meluncurkan sebuah aplikasi yaitu SIMPLE (Sistem Indormasi Manajemen Pembelajaran) yang didalamnya ada perpustakaan digital, video pembelajaran, PPT, LK (lembar kerja), serta e-book.

2) Penyusunan jadwal

Penyusunan jadwal ini dilakukan untuk pembagian tugas dan materi. Pertama, guru memberikan sosialisasi kepada orang tua dulu, jadi bagaimana nanti system e-learning akan dilaksanakan. Ibaratnya guru memberikan sebuah informasi, semua informasi dari Whatsapp, kemudian siswa nanti mengaksesnya melalui penugasan yang ada di classroomnya, semua materi, tugas dikelola, ditampung dalam sebuah LMS classroom. Dari classroom siswa menyimak materi , mengakses materi serta mengerjakan tugas dan mengirimkan tugas melalaui classroom. Selain itu, dalam seminggu 3 kali melaksanakan sinkronus jadi pembelajaran tatap maya atau virtual menggunakan google meet dan zoom.

3) Strategi guru

Pada awalnya guru harus melakukan sosialisasi karena setelah dikaji, masih banyak orang tua yg belum menguasai IT, siswa juga belum bisa menggunakan platform-platform yang akan digunakan. caranya dengan memberikan turotial, panduan dan video. Kemudian setelah itu guru bisa terapkan secara bertahap, tidak semua aplikasi kita terapkan sekaligus. Mungkin dalam seminggu ini pembelajaran memakai aplikasi ini, berikutnya pembelajaran baru masuk ke aplikasi berikutnya. Jadi intinya ada sosialisasi dulu kepada orang tua dan anak-anak, kemudian segala informasi kita sampaikan di grup Whatsapp, baik grup orang tua maupun siswa.

Dari beberapa pelaksanaan pembelajaran e-learning khususnya mata pelajaran Bahasa Indonesia di SDN Margomulyo I menunjukan penggunaan e-learning sudah baik dikarenakan telah menggunakan beberapa aplikasi serta pelaksanaan kegiatan pembelajaran lainnya yang dilakukan di rumah agar membuat siswa tidak merasa bosan dan tertarik untuk mengikuti pembelajaran yang ada namun pastinya dengan kerjasama antara guru dan orang tua dikarenakan peserta didik dalam melaksanakan kegiatan pembelajaran e-learning perlu adanya pemantauan dari guru serta orangtua sendiri, mengingat peserta didik masih dibawah umur.

Penerapan E-Learning sangat relevan dengan pembelajaran membaca karena pembelajaran membaca tidak hanya dilakukan dalam pembelajaran tatap muka, melalui pembelajaran e-learning juga bisa, baik secara sinkronus atau tatap maya melalui Video Conference. Tugas literasi juga bisa dilaksanakan secara asinkronus. Hal ini senada dengan hasil penelitian Nona isnawati (2020) yaitu Pentingnya program pembelajaran e-learning sebagai salahsatu upaya dalam menumbuhkan literasi digital yaitu sebagai sarana untuk menumbuhkan kreatifitas peserta didik dan untuk sarana berbagi informasi.

\section{SIMPULAN}

Berdasarkan hasil penelitian dan pembahasan dapat disimpulkan bahwa Penerapan E-Learning sangat relevan dengan pembelajaran membaca karena pembelajaran membaca tidak hanya dilakukan dalam pembelajaran tatap muka, melalui pembelajaran e-learning juga bisa, baik secara sinkronus atau tatap maya melalui Video Conference. Tugas literasi juga bisa dilaksanakan secara asinkronus. Beberapa aplikasi juga bisa digunakan secara bersamaan an bervarisi.peggunaan aplikasi antara lain google classroom, youtube, Zoom, dan whatsApp serta google workspace for education, google meet, google slide dan google doc. Pengembangan sistem Pembelajaran berbasis internet di SDN Margomulyo I Mengunakan Web centric course atau penggunaan internet yang memadukan antara belajar jarak jauh dan tatap muka, fungsinya saling melengkapi, dalam model ini guru memberikan petunjuk pada siswa untuk mempelajari materi melalui web yang telah dibuat oleh guru. 
Saran dari peneliti bagi guru, guru dituntut harus mampu mendesain kegiatan belajar menggunakan e-learning secara lebih ringan, kreatif namun efektif, dengan memanfaatkan perangkat atau media yang tepat sesuai dengan materi yang hendak disampaikan. Jenis tugas yang diberikan pun harus dirancang sedemikian hingga siswa tetap semangat dalam belajar secara daring dan tidak menjadi beban psikis. Walaupun kegiatan belajar menggunakan e-learning akan memberikan kesempatan lebih luas dalam mengeksplorasi materi yang akan diajarkan, namun guru harus mampu memilih dan membatasi sejauh mana cakupan materinya dan aplikasi yang cocok pada materi dan metode belajar yang digunakan. Guru juga perlu lebih memberi pemahaman kepada siswa bahwa tugas yang diberikan itu bukanlah sebuah beban yang menjadi kewajiban untuk diselesaikan, tetapi adalah sebuah proses yang harus dilalui untuk mempermudah siswa dalam memahami materi.

\section{DAFTAR PUSTAKA}

Ari Kunto, Suharsimi. (2006) .Metodelogi Penelitian.Yogyakarta: Bumi Aksara.

Efendy,Empy dan Hartono Zhuang. (2005). E-learning (Konsep dan Aplikasi).Yogyakarta: Penerbit Andi.

Ibrahim. (2015). Metodelogi Penelitian Kualitataif.Bandung : Alfa Beta.

Isnawati, Nona. (2018). Implementasi Program Pembelajaran Berbasis IT (ELearning) Dalam Menumbuhkan Literasi Digital Di SD Muhammadiyah Condongcatur. Fakultas Ilmu Tarbiyah dan Keguruan Universitas Islam Negeri Sunan Kalijaga Yogyakarta: Tidak Diterbitkan

Kusumana, Ade. (2011). E-learning Dalam Pembelajaran, Jurnal Pendidikan,Vol 14 No 1.

Moleong,Lexy J. (2014). Metodelogi Penelitian Kualitatif. Bandung.Rosda Karya Remaja.

Munir. (2009). Pembelajaran Jarak Jauh. Bandung : Alfa Beta

Poppy, R, Yaniawati.(2010). E-learning dan Alternatif Pembelajaran Kontemporer. Bandung : Arfino Raya

Prawiradilaga,Dewi,Salma.(2013). Mozaik Teknologi Pendidikan E- learning. Jakarta : Pranada Media Group.

Rifa'i, A dan Anni, C.T. (2012). Psikologi Pendidikan. Semarang: Pustaka Pelajar

Sugiyono.(2011).MetodePenelitian Pendidikan (Pendekatan Kualitatif,Kuantitatif, dan $R$ \& D).Bandung : Alfa Beta.

Sugiyono.(2013).Metode Penelitian Kuantitaif, Kualitatif. Bandung: Alfa Beta.

Sugiyono.(2016).Metode Penelitian Kuantitatif, Kualitatif, dan R\&D. Bandung: PT Alfabeta

Tafiardi.(2005).Meningkatkan Mutu Pendidikan Melalui E-Learning. Jurnal Pendidikan Penabur.No.4

Trianto.(2009).Mendesain Model Pembelajaran Inovatif Progresif. Surabaya:Kencana 